\title{
PENGEMBANGAN MEDIA PEMBELAJARAN INTERAKTIF PADA MATERI PENGENALAN COREL DRAW SEBAGAI SARANA PEMBELAJARAN DESAIN GRAFIS DI SMK MUHAMMADIYAH 2 KLATEN UTARA
}

\author{
Alfiyanto Pramuaji \& Muhammad Munir \\ Universitas Negeri Yogyakarta \\ e-mail: alfiyanto.45@gmail.com
}

\begin{abstract}
This study aims to (1) develop learning media introduction of Adobe Flash CS3-based coreldraw for students of class X of multimedia majors in SMK Muhammadiyah 2 Klaten Utara; \& (2) know the feasibility of instructional media that has been produced as the teaching materials for students. The development model used in this research is the ADDIE model. The results showed that: (1) Development of Interactive Learning Media the introduction of CorelDraw on Graphic Design subjects produce interactive learning media products containing seven basic competencies and equipped with video tutorials. In this learning media there is also a tutorial to create an object for training and practice about evaluation; and (2) the level of media learning appropriateness of material experts by $88 \%$ with very decent category, media experts of $82.5 \%$ with very decent category, and student assessment To the learning media of $81 \%$ with very decent category. Based on the results of this study, interactive learning media introduction of Flash-based coreldraw worthy to be used as a teaching tool in the learning process at school.
\end{abstract}

Keywords: Learning Media, Adobe Flash CS3, Feasibility

\begin{abstract}
ABSTRAK
Penelitian ini bertujuan untuk (1) mengembangkan media pembelajaran pengenalan corel draw berbasis Adobe Flash CS3 untuk siswa kelas X jurusan multimedia di SMK Muhammadiyah 2 Klaten Utara; dan (2) mengetahui kelayakan media pembelajaran yang dihasilkan telah memenuhi sebagai bahan ajar bagi siswa. Model pengembangan yang digunakan adalah model ADDIE. Hasil penelitian menunjukkan bahwa: (1) Pengembangan Media Pembelajaran Interaktif pengenalan CorelDraw pada mata pelajaran Desain Grafis menghasilkan produk media pembelajaran interaktif yang berisikan tujuh kompetensi dasar dan dilengkapi dengan video tutorial. Pada media pembelajaran ini juga terdapat tutorial membuat sebuah objek untuk latihan dan latihan soal evaluasi; dan (2) tingkatkelayakan media pembelajaran dari ahli materi sebesar $88 \%$ dengan kategori sangat layak, ahli media sebesar 82,5\% dengan kategori sangat layak, dan penilaian siswa terhadap media pembelajaran sebesar $81 \%$ dengan kategori sangat layak. Berdasarkan hasil penelitian tersebut maka media pembelajaran interaktif pengenalan corel draw berbasis Flash layak digunakan sebagai alat bantu mengajar dalam proses pembelajaran di sekolah.
\end{abstract}

Kata Kunci: Media Pembelajaran, Adobe Flash CS3, Kelayakan

\section{PENDAHULUAN}

Minimnya penggunaan media pembelajaran berbasis Multimedia di SMK Muhammadiyah 2 Klaten Utara dalam proses belajar mengajar yang digunakan oleh pendidik atau guru, dikarenakan metode yang digunakan oleh pendidik atau guru di SMK Muhammadiyah 2 Klaten Utara kurang bervariasi dalam hal penggunaan media pembelajaran. Masalah belajar mengajar di sekolah yang masih sering dijumpai diantaranya proses pembelajaran yang kurang menarik minat peserta didik, peserta didik 
cenderung hanya pasif dalam menerima materi pelajaran.

Berdasarkan hasil observasi dari pengamatan selama di sekolah, ada beberapa faktor yang menyebabkan proses belajar peserta didik menjadi sering terkendala. Faktor-faktor tersebut diantaranya setiap siswa memiliki kemampuan daya serap materi yang berbeda-beda. Dengan perbedaan ini guru harus peka untuk dapat mengarahkan siswanya sesuai dengan kemampuan, minat dan bakat yang dimiliki oleh siswa sehingga potensi yang ada dalam diri siswa dapat dikembangkan secara optimal.

Penerapan media untuk belajar kurang optimal. Beberapa materi pembelajaran masih belum ada media untuk belajar. Dengan adanya media belajar yang tepat, siswa dapat lebih terfokus dalam proses pembelajaran. Pada zaman modern ini, media pembelajaran telah menjadi salah satu komponen yang penting dalam sebuah pembelajaran.

Guru tidak hadir di kelas karena ada rapat, sehingga proses KBM tidak bisa berjalan. Beberapa siswa ada kegiatan OSIS, siswa yang menjadi anggota OSIS selama ada kegiatan OSIS tidak mengikuti proses KBM. Beberapa siswa mengikuti kegiatan perlombaan antar sekolah, sehingga siswa yang mewakili sekolah tidak dapat mengikuti proses KBM selama mengikuti lomba tersebut. Siswa diharuskan mengejar ketertinggalan materi dengan belajar secara mandiri.

Berdasarkan diskusi dengan guru mata pelajaran Kompetensi Keahlian Multimedia, dengan pokok bahasan pengenalan CorelDraw pada mata pelajaran Desain Grafis yang mempunyai tingkat kesulitan tersendiri bagi siswa terutama dalam hal pengoperasian softwareCorelDraw dan belum adanya media pembelajaran yang digunakan pada pokok bahasan CorelDraw. Khususnya untuk Kelas $\mathrm{X}$ Multimedia masih banyak siswa mengalami kesulitan dalam pengoprasian software CorelDraw. Hal ini dapat dilihat ketika guru mendemostrasikan langkah pembuatan suatu desain kipas dengan di depan kelas masih banyak siswa yang kesulitan dalam mengikuti langkah pembuatan desain tersebut, sehingga guru harus menjelaskan berkali-kali dan terkadang juga guru harus mendatangi tempat kerja siswa (komputer siswa) untuk menjelaskan kembali, lalu guru baru dapat melanjutkan ke langkah selanjutnya.

Berdasarkan permasalahan yang telah diuraikan, perlu adanya media pembelajaran yang menarik, efektif dan mudah digunakan. Untuk itu, dalam penelitian ini dilakukan Pengembangan media pembelajaran interaktif pengenalan CorelDraw pada mata pelajaran Desain Grafis di SMK Muhammadiyah 2 Klaten Utara. Dengan dibuatnya media pembelajaran ini diharapkan siswa akan lebih tertarik dalam mengikuti KBM. Media ini dibangun dari awal atau sebelumnya belum ada sehingga belum diketahui kualitas dari media lunak tersebut. Untuk mengetahui kualitas kelayakan media ini digunakan suatu standard internasional yaitu ISO 9126.

Berdasarkan paparan pendahuluan yang ada, selanjutnya dapat dirumuskan masalah sebagai berikut: (1) Bagaimana mengembangkan media pembelajaran interaktif pengenalan CorelDraw pada mata pelajaran Desain Grafis di SMK Muhammadiyah 2 Klaten Utara ? (2) Bagaimana kelayakan media pembelajaran interaktif pengenalan CorelDraw pada mata pelajaran Desain Grafis di SMK Muhammadiyah 2 Klaten Utara?

Media yang dikembangkan akan diuji oleh ahli materi, ahli media, dan siswa kelas $\mathrm{X}$ multimedia untuk mengetahui kualitas media yang dikembangkan. Adanya pemanfaatan media pembelajaran interaktif pengenalan Corel Draw pada mata pelajaran Desain Grafis diharapkan mampu menarik siswa dalam mengikuti KBM.

Definisi dari media yang berasal dari bahasa latin dan merupakan bentuk jamak dari kata medium yang secara harfiah berarti perantara atau pengantar. Media adalah segala sesuatu yang dapat digunakan untuk menyalurkan pesan dari pengirim ke penerima sehingga dapat merangsang pikiran, perasaan, 
perhatian, dan minat serta perhatian siswa sedemikian rupa sehingga proses belajar terjadi (Sadiman,2011:6).

Selanjutnya mengenai pembelajaran, Gagne dan Briggs ( 1979:3 ) mengungkapkan pengertian pembelajaran sebagai suatu sistem yang bertujuan untuk membantu prosesbelajar siswa, yang berisi serangkaian peristiwa yang dirancang, disusun sedemikian rupa untuk mempengaruhi dan mendukung terjadinya proses belajar siswa yang bersifat internal.

Sharon E, Smaldino, et.al., dalam Pujiriyanto (2012: 20) menyatakan media yang menyajikan pesan - pesan terkait dengan tujuan pembelajaran disebut dengan media pembelajaran. Gagne dan Briggs dalam Azhar Arsyad (2014: 4) secara implisit mengatakan bahwa media pembelajaran meliputi alat yang secara fisik digunakan untuk menyampaikan isi materi pengajaran, yang terdiri dari antara lain buku, tape recorder, film, slide (gambar bingkai), foto, gambar, grafik, televisi, dan komputer.

Menurut Pujiriyanto (2012: 160), media interaktif merupakan sistem penyajian bahan pembelajaran yang direkam (visual, suara dan video) dan ditampilkan dengan kontrol komputer. Pengguna tidak sekedar melihat dan mendengarkan penyajian namun terlibat merespon secara aktif, dan respon pengguna menentukan laju dan urutan penyajian. Mustholiq (2007) berpendapat bahwa penggunaan media interaktif bertujuan untuk membuat peserta didik mampu mengembangkan pengetahuannya tentang apa yang telah dipelajari.

Dalam kasus media pembelajaran pada penelitian ini, karakteristik yang akan diteliti terkait media pembelajaran yang dibuat mengacu pada dua karakteristik berikut: (1) Functionality mencakup: Suitability, Accurateness, Interoperability, dan Security; serta (2) Usability mencakup: Understandability, Learnability, Operability, dan Attractiveness.

\section{METODE}

Metode penelitian yang digunakan adalah metode penelitian dan pengembangan atau Research and Development yang berarti suatu proses atau langkah-langkah untuk mengembangkan suatu produk baru atau menyempurnakan produk yang sebelumnya telah ada yang dapat dipertanggungjawabkan (Sujadi, 2003: 164).

Model pengembangan media pembelajaran interaktif yang digunakan dalam penelitian ini adalah model pengembangan ADDIE yaitu needs assessment, front-end analysis, design, development, implementation, dan evaluation (Lee dan Owens, 2004: 3) yang telah dimodifikasi sehingga menghasilkan sebuah model pengembangan yang lebih sederhana untuk penelitian pemula yang sudah dipadukan pada langkah-langkah penelitian pengembangan.

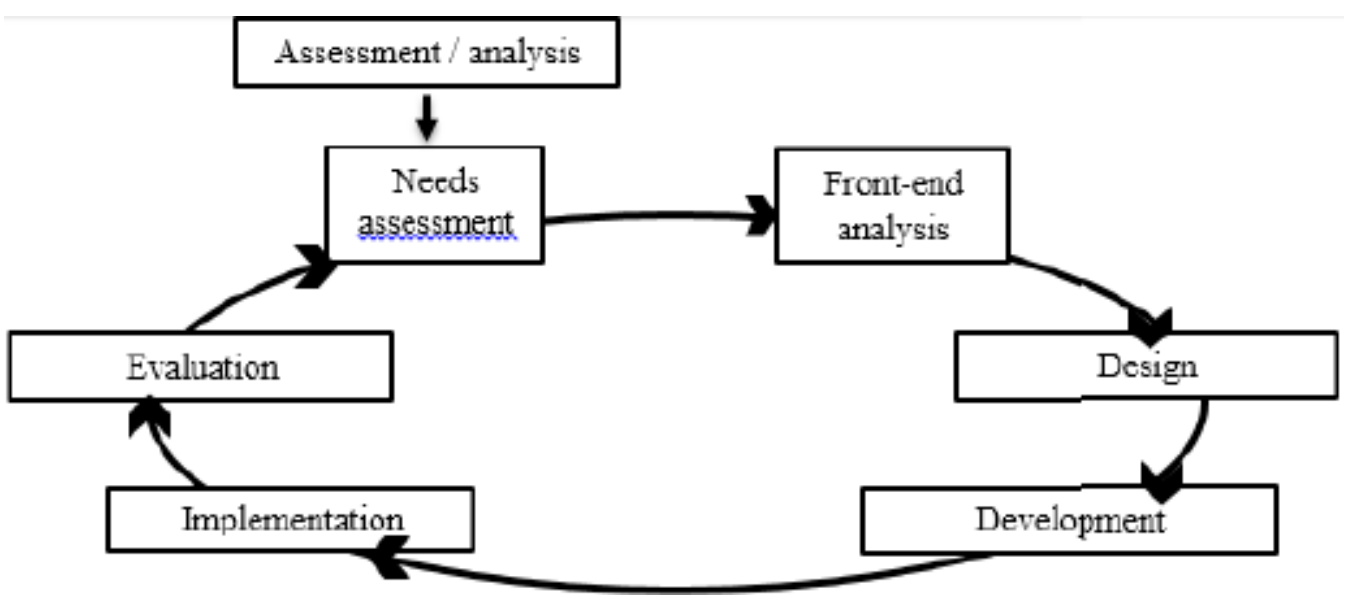

Gambar 1. Model Pengembangan ADDIE 
Pada tahap analisis terdiri dari dua tahap, yaitu tahap analisis kebutuhan (needs assessment) dan front-end analysis. Tahap desain adalah sebuah perencanaan yang merupakan tahapan dalam menyusun langkahlangkah persiapan yang akan dilakukan dalam pembuatan produk. Tahap pengembangan merupakan tahap untuk proses mewujudkan desain menjadi kenyataan, artinya tahapan ini segala sesuatu yang dibutuhkan dan yang mendukung proses pembelajaran semuanya harus disiapkan. Implementasi adalah langkah nyata untuk menerapkan sistem pembelajaran yang dibuat. Artinya, semua yang dikembangkan diinstal sedemikian rupa sesuai dengan peran atau fungsinya agar bisa diimplementasikan. Evaluasi adalah proses untuk melihat apakah produk yang dikembangkan berhasil sesuai dengan harapan awal atau tidak.

Subjek dalam penelitian meliputi ahli media, ahli materi, dan Calon Pengguna. Penelitian ini dilakukan di SMK Muhammadiyah 2 Klaten Utara. Waktu yang digunakan untuk melakukan penelitian adalah semester genap Tahun Ajaran 2016/2017. Teknik pengumpulan data menggunakan model kuisioner. Kuisioner adalah teknik pengumpulan data melalui formulir-formulir (angket) yang berisi pertanyaan-pertanyaan yang diajukan secara tertulis pada seseorang atau sekumpulan orang untuk mendapatkan jawaban atau tanggapan dan informasi yang diperlukan peneliti (Mardalis, 2004: 67). Kuisioner yang diterapkan baik untuk uji coba lapangan maupun untuk uji kualitas produk menggunakan model kuisioner tertutup atau dengan kata lain sudah disediakan pilihan jawabannya untuk dipilih oleh responden.

Instrumen penelitian adalah alat yang digunakan untuk mengolah dan menginterpretasikan hasil uji coba produk (Muhammad Munir, 2014). Angket penelitian atau kuesioner yang digunakan merupakan angket yang telah dibuat peneliti berdasarkan turunan dari teori yang digunakan, lalu dijadikan dalam kisi-kisi instrumen yang juga telah dikonsultasikan sebelumnya, dan kemudian instrumen tersebut divalidasi oleh 4 orang ahli yaitu 2 orang ahli untuk instrumen yang diperuntukkan bagi ahli materi dan 2 orang ahli untuk instrumen yang diperuntukkan bagi ahli media dan pengguna media.

Teknik analisis data yang digunakan adalah skala Likert. Skala Likert digunakan untuk mengukur sikap, pendapat, dan persepsi seseorang atau sekelompok orang tentang fenomena sosial (Sugiyono, 2011: 93). Tabel skala Likert dapat dilihat pada Tabel 1. Data akan dikonversikan menjadi nilai dengan 5 skala yaitu satu, dua, tiga, empat, dan lima. Untuk mendapatkan besar persentase kelayakan media, secara matematis digunakan persamaan rating scale seperti berikut ini.

$P K(\%)=\frac{\text { Skor yang diobservasi }}{\text { Skor yang diharapkan }} \times 100 \%$

Keterangan:

PK:Presentase Kelayakan (Sugiyono, 2011: 99)

Pembagian kategori kelayakan didapat dari membagi rentang bilangan persentase sesuai dengan skala Likert (Arikunto, 2009: 35). Jika diharapkan kondisi dari hasil penelitian adalah $100 \%$, maka nilai rentang tersebut akan dibagi menjadi 5 kategori sesuai dengan skala Likert. Hasil pengelompokkan rentang kategori kelayakan media dapat dilihat pada Tabel 2.

Tabel 1. Skala Likert (Sumber: Sugiyono, 2011: 95)

\begin{tabular}{lc}
\hline \multicolumn{1}{c}{ Kategori } & Skor \\
\hline Sangat Tidak Setuju (STS) & 1 \\
Tidak Setuju (TS) & 2 \\
Cukup Setuju (CS) & 3 \\
Setuju (ST) & 4 \\
Sangat Setuju (SS) & 5 \\
\hline
\end{tabular}


Tabel 2. Kategori Kelayakan (Sumber: Suharsimi Arikunto, 2013: 35)

\begin{tabular}{cc}
\hline Interval Persentase & Nilai \\
\hline$<21 \%$ & Sangat Tidak Layak \\
$21 \%-40 \%$ & Tidak Layak \\
$41 \%-60 \%$ & Cukup Layak \\
$61 \%-80 \%$ & Layak \\
$81 \%-100 \%$ & Sangat Layak \\
\hline
\end{tabular}

\section{HASIL}

Pengembangan media pembelajaran dirancang menggunakan metode ADDIE terdiri dari beberapa tahapan yang meliputi needs assessment and front-end analysis, design, development, implementation, dan evaluation (Lee dan Owens, 2004: 3). Tahap pertama, tahap analisis kebutuhan (needs assessment and front-end analysis) adalah tahap pengumpulan informasi tentang kondisi pembelajaran di SMK Muhammadiyah 2 Klaten Utara dan mengumpulkan referensi mengenai pokok bahasan yang dipilih yaitu pengenalan coreldraw. mengumpulkan referensi yaitu berupa kurikulum, silabus mata pelajaran, buku-buku yang berkaitan dengan materi, ebook, buku tentang program aplikasi komputer yaitu Adobe Flash CS6 dan semua yang dibutuhkan dalam pengembangan produk seperti gambar, foto, animasi, video, font, audio, dan lain-lain yang akan digunakan dalam pengembangan produk.

Tahap kedua, tahap desain (design) adalah perancangan media pembelajaran interaktif yang meliputi pembuatan flowchart, pembuatan desain secara keseluruhan (storybord), pengumpulan objek rancangan, dan penyusunan instrumen untuk uji kelayakan. Tahap ketiga, tahap pengembangan (development) adalah Seluruh komponen dirangkai menjadi satu kesatuan media sesuai dengan storyboard dan flowchart yang sudah dirancang. Tahap keempat, tahap implementasi (implementation) adalah tahap pengujian media pembelajaran terhadap pegguna akhir media yaitu siswa kelas $\mathrm{X}$ Multimedia SMK Muhammadiyah 2 Klaten
Utara. Tahap kelima, tahap evaluasi (evaluation) adalah menganalisis data dari validasi kelayakan produk oleh ahli materi dan media,dan menganalisis data yang diperoleh dari siswa untuk mengetahui kelayakan media.

Kelayakan media pembelajaran ditentukan oleh data yang diperoleh dari ahli materi, ahli media, dan pengguna. Data yang diperoleh pada tahap pengujian kelayakan ahli materi diolah menggunakan Microsoft Excel. Berdasarkan data tersebut, peneliti memperoleh persentase kelayakan materi, kemudian persentase tersebut diubah menjadi kategori kelayakan. Penentuan ini berdasarkan pada table skala persentase kelayakan menurut Suharsimi Arikunto. Hasil kelayakan ahli materi dapat dilihat pada Tabel 3.

Tabel 3. Hasil kelayakan ahli materi

\begin{tabular}{lll}
\hline Ahli & I & II \\
\hline Skor total & 87 & 78 \\
Persentase & $87 \%$ & $78 \%$ \\
Rerata persentase & $82,5 \%$ & \\
\hline
\end{tabular}

Berdasarkan pada Tabel 3, diperoleh hasil penilaian kelayakan ahli materi diperoleh peresentase kelayakan $87 \%$ ahli materi I, $78 \%$ ahli materi II. Jadi rerata penilaian kedua ahli materi diperoleh persentase kelayakan sebesar $82.5 \%$ dan masuk kategori sangat layak.

Data yang diperoleh pada tahap pengujian kelayakan ahli media diolah menggunakan Microsoft Excel. Berdasarkan data tersebut, peneliti memperoleh persentase kelayakan media, kemudian persentase tersebut diubah menjadi kategori kelayakan. Penentuan ini berdasarkan pada table skala persentase kelayakan menurut Suharsimi Arikunto. Hasil kelayakan ahli media dapat dilihat pada Tabel 4.

Tabel 4. Hasil Kelayakan ahli media

\begin{tabular}{lll}
\hline Ahli & I & II \\
\hline Skor total & 86 & 90 \\
Persentase & $86 \%$ & $90 \%$ \\
Rerata persentase & $88 \%$ & \\
\hline
\end{tabular}


Berdasarkan pada Tabel 4, diperoleh hasil penilaian kelayakan ahli media diperoleh peresentase kelayakan $86 \%$ ahli media I, $90 \%$ ahli media II. Jadi rerata penilaian kedua ahli media diperoleh persentase kelayakan sebesar $88 \%$ dan masuk kategori sangat layak.

Berdasarkan data penilaian pengguna dari 26 siswa kelas $\mathrm{X}$ jurusan multimedia diperoleh hasil rerata penilaian keseluruhan dari siswa diperoleh persentase kelayakan sebesar $81 \%$ dan masuk kategori sangat layak. Penilaian memang dikategorikan sangat layak, tetapi ada penilaian paling rendah pada aspek usabilitas bagian kesesuaiaan kebutuhan, sedangkan penilaiaan skor maksimal pada aspek usabilitas bagian membantu dalam proses belajar.

\section{SIMPULAN}

Berdasarkan hasil penelitian dan pembahasan maka dapat diambil kesimpulan sebagai berikut: (1) pengembangan Media Pembelajaran Interaktif pengenalan CorelDraw pada mata pelajaran Desain Grafismenghasilkan produk media pembelajaran interaktif yang berisikan tujuh kompetensi dasar dan dilengkapi dengan video tutorial. Pada media pembelajaran ini juga terdapat tutorial membuat sebuah objek untuk latihan dan latihan soal evaluasi; dan (2) hasil pengujian kelayakan media pembelajaran oleh ahli materi menunjukkan $82,5 \%$ dengan kategori sangat layak, untuk ahli media menunjukkan $88 \%$ dengan kategori sangat layak, dan penilaian siswa terhadap media pembelajaran dalam aspek usability adalah $81 \%$ dengan kategori sangat layak. Berdasarkan hasil pengujian tersebut maka Media Pembelajaran Interaktif Pengenalan CorelDraw pada Pelajaran Desain Grafis layak digunakan dalam proses pembelajaran.

Saran dari peneliti untuk penelitian pengembangan produk selanjutnya adalah sebagai berikut: (1) siswa menggunakan media pembelajaran interaktif pengenalan coreldraw sebagai media pembelajaran untuk mendukung kegiatan belajar mengajar dan sarana belajar mandiri serta sebagai landasan untuk berinovasi dalam bidang Multimedia; (2) pendidik menggunakan media pembelajaran interaktif pengenalan coreldraw dalam strategi pembelajaran pada mata pelajaran Desain Grafis. Selain itu guru sebaiknya juga ikut mengembangkan media serupa agar sarana pembelajaran bervariasi; dan (3) penelitian merupakan penelitian pengembangan dengan tujuan menghasilkan produk dan menguji tingkat kelayakannya. Peneliti berharap akan adanya penelitian pengembangan yang dilakukan sampai pengaruhnya terhadap siswa, yaitu bertambahnya pemahaman siswa. Selain itu media pembelajaran interaktif juga diuji tingkat keefektifitannya dalam kegiatan pembelajaran.

\section{DAFTAR PUSTAKA}

Arsyad, Azhar. 2014. Media Pembelajaran. Jakarta: Rajawali Pers.

Gagne amd Briggs.L.J. 1979. Principles Of Instructional Design. New York : Holt Rinehart and Winston.

Munir, Muhammad. 2014. Pengembangan Media Pembelajaran Interaktif Kompetensi Dasar Register Berbasis Inkuiri Terbimbing. Journal Pendidikan Teknologi dan Kejuruan.22 (2), 184190.

Mustholiq, Imam, dkk. 2007.Pengembangan Media Pembelajaran Interaktif Berbasis Multimedia Pada Mata Kuliah Dasar Listrik. Journal Pendidikan Teknologi dan Kejuruan. 16 (1), 1-18.

Pujiriyanto. 2012. Teknologi untuk Pengembangan Media dan

Pembelajaran. Yogyakarta: UNY Press.

Gafur. 2001. Desain Instruksional (Suatu Langkah Sistematis Penyusunan Pola Kegiatan Belajar dan Mengajar). Solo: Tiga Serangkai 
Knirk, F.G. dan Gustafson, K.L. 2005. . Instructional Tecnology a Systematic Approach to Education. New York: Hlt Rinehart and Winston.

Mardalis. 2004. Metode Penelitian, Suatu Pendekatan Proposal. Jakarta: Bumi Aksara.
Sadiman, Arif, dkk. 2011. Media Pendidikan: Pengertian, Pengembangan, dan Pemanfaatan. Ed. 1-15 Jakarta: Rajawali Pers. Rajagrafindo Persada 